\title{
Targeting Akt by SC66 triggers GSK-3 $\beta$ mediated apoptosis in colon cancer therapy
}

\author{
Yeying Liu', Yuan Huang ${ }^{1}$, Jie Ding ${ }^{3}$, Nannan Liu' ${ }^{1}$, Shuang Peng ${ }^{1}$, Jiangang Wang ${ }^{1 *}$, Feng Wang ${ }^{2 *}$
} and Yingjie Zhang ${ }^{1,4^{*}}$ (D)

\begin{abstract}
Background: Colon cancer is one of the three common malignant tumors, with lower 5 years survival rate. Akt is an important therapeutic target, while SC66 is a novel allosteric AKT inhibitor, which enhances the therapeutic effect in several types of cancer. However, the molecular mechanisms of targeting AKT by SC66 during colon cancer therapy are not well understood.
\end{abstract}

Methods: The biological role of GSK-3ß in colon cancer growth suppression induced by SC66 was detected in vitro and in vivo. Hoechst 33342 and crystal violet staining were used to determine whether targeting AKT affected apoptosis and cell proliferation. The CCK8 assay was utilized to analyze cell viability. The expression levels of Akt, GSK-3 $\beta$, $\mathrm{Bax}, \mathrm{BCl}-\mathrm{xL}, \mathrm{p} 53$ and PUMA were measured by immune blotting. Xenograft mouse model was established to study the antitumor effect of SC66 in vivo.

Results: Our results show that SC66 induced significantly colon cancer cell apoptosis, accompanied with Akt inactivation. After AKT inhibition, activated GSK-3 $\beta$ interacted with Bax directly, leading to Bax oligomerization and activation. Knocking down GSK-3 $\beta$ abrogated SC66-triggered Bax activation and apoptosis, which was enhanced by over-expressed GSK-3ß. In addition, the expression level of BCl-xL was down-regulated while p53 had no function during SC66-induced apoptosis. Furthermore, colon cancer growth was suppressed by SC66 therapy in vivo.

Conclusion: Taken together, these data indicated that the novel small molecule AKT inhibitor SC66 shows visible antitumor effects via the AKT/GSK-3 $3 /$ Bax axis in vitro and in vivo. Our results provide a rational basis for the development of targeting-GSK-3 $\beta$, which may serve as a potential biomarker and yield meaningful benefits for colon cancer patients in the future.

Keywords: AKT, GSK-3ß, BCl-xL, SC66, Colon cancer

\section{Background}

Colon cancer is a frequent occurrence in malignancies of digestive tract with an increasing mortality rate, but a low 5-year survival rate [1]. Many significant therapeutic agents over the past decade have been applied for colorectal cancer therapy $[2,3]$. However, chemotherapeutic

\footnotetext{
*Correspondence: wangzigangcsu@hotmail.com; 1244230442@qq.com; yingjiezhang@hnu.edu.cn

${ }^{1}$ Department of Health Management, The Third Xiangya Hospital, Central South University, College of Biology, Hunan University, No. 1, Denggao

Road, Changsha, China

${ }^{2}$ Department of Gastroenterology, The Tenth People's Hospital of Shanghai, Tongji University, Shanghai, China

Full list of author information is available at the end of the article
}

agents gradually turn out to show its drawbacks due to lack of specificity or drug resistances $[4,5]$. In this regard, potential drugs with specific target are now being developed for clinical application to cure colorectal cancer patients.

SC66, a novel AKT inhibitor, has shown greater promise than other PIP3/Akt inhibitors against several cancer types, including cervical cancer [6]. As an allosteric AKT inhibitor, SC66 facilitates Akt deactivation more effectively by directly interfering with the PH domain binding to PIP3, and subsequently induces Akt ubiquitination, thereby manifesting a more efficient growth suppression of transformed cells that are associated with a high-level expression of Akt signaling [7]. 
SC66 also induces alterations in cytoskeleton organization and ROS production, leading to a reduction in total and phospho-AKT levels. SC66 has been demonstrated to inhibit tumor growth of hepatocellular carcinoma significantly via the AKT/mTOR/ $\beta$-catenin pathway [8]. However, the mechanisms by which SC66 exerts its antitumor activity especially how to induce cell apoptosis are not well-understood.

One of the most typically activated pathways in human colon cancer is the PI3K/AKT signaling, which has been involved in tumor initiation, invasion, vascularization and metastasis [9-12]. It is therefore not surprising that this inappropriately activated signaling contributes to making the AKT important therapeutic target. AKT, also known as protein kinase $\mathrm{B}(\mathrm{PKB})$, is a serine/threonine kinase that mediates cell proliferation, protein synthesis, transcription, and apoptosis [13-15]. And its kinase activity is positively mediated by phosphorylation on two key residues Ser473 and Thr308 [16]. Phosphorylation of both residues on is required for maximal AKT1 activation downstream of PI3K [17]. Once activated by a variety of apoptotic stimuli, AKT inhibits the function of the critical tumor suppressor p53 and promotes survival [18]. In addition, several myriad substrates, such as Forkhead Box O3a (FoxO3a), nuclear factor $\kappa \mathrm{B}(\mathrm{NF}-\mathrm{\kappa} \mathrm{B})$ and the mammalian target of rapamycin (mTOR), may be activated via the PI3K/ Akt axis $[11,19,20]$. Akt phosphorylates and inhibits several pro-apoptotic gene activities such as Bad, Bim and procaspase $9[10,15,21,22]$. Importantly, activated AKT protects cells from pro-apoptotic stimuli as well as inhibiting GSK-3 $\beta$ [23].

Glycogen synthase kinase-3 $\beta$ (GSK-3 $\beta$ ) is a key mediator of apoptosis responding to numerous stimuli $[24,25]$. Current studies have demonstrated that active GSK-3 $\beta$ promotes the mitochondrial localization of Bax and induces neuronal apoptosis in response to staurosporine or heat shock [26, 27]. Several Bcl-2 family members are direct substrates/indirect targets of GSK-3 $\beta$ [13]. For example, activated GSK- $3 \beta$ phosphorylates the transcription factor c-Myb, leading to the altered level of $\mathrm{Bcl}-2$ [28, 29]. Pro-apoptotic BH3-only members such as PUMA, $\mathrm{Bim}$, and Bid, indirectly or directly activate the multi-BH domain containing pro-apoptotic signals Bax/Bak, which triggers Bax oligomerization and subsequently causes downstream events including mitochondrial outer membrane permeabilization (MOMP), caspase cascade, and apoptosis [30-33]. Bcl-xL, a critical pro-survival Bcl-2 family member, suppresses apoptosis through the hydrophobic BH3 domain-binding groove of pro-apoptotic signals [34]. Several studies reported certain solid tumor cell lines with low Bcl-xL were sensitive to conventional therapies.

\section{Materials and methods}

Cell culture and treatment

The human colon cancer cell lines, HCT-116, RKO and DLD1 were obtained from American type culture collection (ATCC). Human colon cancer cell line with

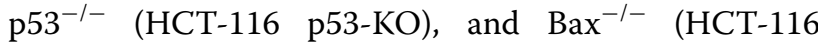
Bax-KO) were generously provided by Dr Bert Vogelstein (Johns Hopkins University, Baltimore, MD, USA). All the cell lines were routinely cultured in McCoy's 5A modified medium, supplemented with $10 \%$ fetal bovine serum (FBS), penicillin (100 units $/ \mathrm{ml})$, and streptomycin $(100 \mathrm{mg} / \mathrm{ml})$ in $5 \% \mathrm{CO} 2$ at $37^{\circ} \mathrm{C}$ in humidified incubator. SC66 was purchased from Selleck Chemicals (Houston, TX). The agent of SC66 diluted with DMSO were added in the medium directly. For treatment, the anticancer agent was added in the medium directly before detection.

Transfections were performed with Lipofectamine ${ }^{\mathrm{TM}}$ 2000 reagent according to the manufacturer's protocols (7 sea biotech, Shanghai, China). Cells were transfected with either an empty vector or a constitutively-active Akt expression constructs for $48 \mathrm{~h}$. Then added the related drugs into the culture medium, and replaced with fresh culture medium after $6 \mathrm{~h}$ and kept for $12 \mathrm{~h}$. Finally, cells were harvested and proteins were examined to at $24-48 \mathrm{~h}$ after transfection.

\section{Antibodies and reagents}

Primary antibodies against p53, Phospho-Akt (S473), Total-Akt, Phospho-GSK-3 $\beta$, GSK-3 $\beta$, Bax, Bcl-2, Bcl-XL, Mcl-1, Cox IV, Cleaved-Caspase 3 and $\beta$-actin were purchased from Cell Signaling Technology. Lipofectamine ${ }^{\mathrm{TM}}$ Reagent was purchased from Invitrogen. HRP-conjugated anti-rabbit and or anti-mouse secondary antibodies an ECL-plus kit were from GE Healthcare. SC66 was purchased from Selleck Chemicals (Houston, TX). The oligonucleotide for shGSK-3 was synthesized as 5'-CCG GGTGTGGATCAGTTGGTAGAAACTCGAGTTTCT ACCAACTGATCCACACTTTTT-3'. The CCK-8 kit was from 7 sea biotech (Shanghai, China).

\section{Cell viability and apoptosis assays}

Colon cancer cells were cultured in 96-well microplate at a density of $3.5 \times 10^{3}$ cells/well for $24 \mathrm{~h}$. Cell viability was assessed with CCK-8 at indicated time post treatment according to the manufacturer's instructions. To estimate the viability of the cells, the absorbance of $450 \mathrm{~nm}$ (OD450) was measured with a 96-well plate reader (DG5032, Huadong, Nanjing, China).

For analysis of apoptosis by Hoechst 33342 (Invitrogen), colon cells were cultured on the coverslip of a chamber, rinsed with phosphate-buffered saline (PBS) twice, and then added in $1 \mathrm{ml}$ of McCoy's 5A containing $1 \mu \mathrm{l}$ Hoechst 33342, incubated at $37{ }^{\circ} \mathrm{C}$ with $5 \%$ 
$\mathrm{CO}_{2}$ for 15 or $20 \mathrm{~min}$. Apoptosis was assessed through microscopic visualization of condensed chromatin and micronucleation.

For colony formation assays, equal number of cells after different treatments were plated into 6-well plates. Medium was changed every 2 days. Colonies were visualized by crystal violet staining 2 weeks after plat.

\section{Western blotting}

Protein samples were extracted with RIPA buffer $(10 \mathrm{mM}$ Tris- $\mathrm{HCl}$ (pH 8.0), 1 mM EDTA, 0.5 mM EGTA, 1\% Triton X-100, 0.1\% sodium deoxycholate, 0.1\% SDS. $140 \mathrm{mM}$ $\mathrm{NaCl})$. Equivalent protein samples $(30 \mu \mathrm{g}$ protein extract was loaded on each lane) were subjected to SDS-PAGE on $10 \%$ gel or $12 \%$ gel. The proteins were then transferred onto PVDF membranes (Millipore) and blocked with $5 \%$ non-fat milk for $1 \mathrm{~h}$ at room temperature. The membranes, probed with the indicated primary antibodies, were then incubated at $4{ }^{\circ} \mathrm{C}$ overnight. Primary antibody was detected by binding horseradish peroxidase (HRP)conjugated anti-rabbit or anti-mouse secondary antibody with an ECL plus kit. Detection was performed using the Odyssey infrared imaging system (LI-COR, Lincoln, NE). To detect Bax multimerization, purified mitochondrial fractions were cross-linked with DSP [dithiobis (succinimidyl propionate)] (1 mmol/l), followed by Western blotting analysis.

\section{Flow cytometry}

After treatment, human colon cancer cell line with HCT116 WT, p53 ${ }^{-1-}$ (HCT-116 p53-KO), DLD1 and Bax ${ }^{-1-}$ (HCT116 Bax-KO) were suspended in $1 \times 10^{5}$ cells $/ \mathrm{ml}$, and $5 \mu \mathrm{l}$ Annexin $\mathrm{V}$ and $5 \mu \mathrm{l}$ propidium iodide staining solution were added to $100 \mu \mathrm{l}$ of the cell suspension. Then added $400 \mu \mathrm{l}$ Binding Buffer to the cell suspension again. After the cells were incubated at room temperature for $10 \mathrm{~min}$ in the dark, stained cells were assayed and quantified using a FACSort Flow Cytometer (Beckman Coulter, Brea, CA, USA). Cell debris was excluded from the analysis by an appropriate forward light scatter threshold setting. Compensation was used wherever necessary.

\section{Co-immunoprecipitation}

To detect the interaction between GSK-3 $\beta$ and Bax, about $4 \mathrm{ml}$ of GSK-3 $\beta$ or Bax antibodies respectively were firstly added to $400 \mathrm{ml}$ cell lysates. According to the manufacturer's protocol, the mixtures were mixed on a rocker at ambient temperature for $2 \mathrm{~h}$. The immunocomplexes were captured by the addition of protein A-agarose (Roche Applied Sciences, Indianpolis, Cat. No. $11134515001)$ mixed at 1:10 ratio, followed by incubation at ambient temperature for $1 \mathrm{~h}$. The beads were washed by Washing Buffer 1, Washing Buffer 2, Washing
Buffer 3 (Roche Applied Sciences, Indianpolis, Cat. No. 11134515001 ) and then collected by centrifugation at $12,000 \mathrm{rpm}$ for $30 \mathrm{~s}$. After the final wash, the beads were mixed with $60 \mathrm{ml}$ of $2 \times$ Laemmli sample buffer, heated at $98{ }^{\circ} \mathrm{C}$ for $8 \mathrm{~min}$, and analyzed by Western blotting using GSK-3 $\beta$, Bax6A7 or Bax antibody (Cell Signaling Technology, Shanghai, China).

\section{Xenograft mouse model and treatment}

Female 5-week-old nude mice (Vital River, China) were housed in a sterile environment with micro isolator cages and allowed access to water and chow ad libitum. HCT-116 WT was harvested, and $1 \times 10^{6}$ cells in $0.2 \mathrm{ml}$ of McCoy's 5A modified medium were implanted subcutaneously into the back of athymic nude female mice. Mice were treated with daily with SC66 at $25 \mathrm{mg} / \mathrm{kg}$ by i.p. injection every other 3 days for 15 days, whereas the control mice were administered vehicle. Volume was calculated by the formula of $0.5 \times$ length $\times$ width $^{2}$. Mice were euthanized when tumors reached $\sim 1.0 \mathrm{~cm}^{3}$ in size. Tumors were dissected and fixed in $10 \%$ formalin and embedded in paraffin. All mice were housed and maintained under specific pathogen-free (SOPF) conditions. All animal studies were in accordance with institutional guidelines and approved by the Use Committee for Animal Care.

\section{Statistical analysis}

Statistical analyses were performed using GraphPad Prism V software. All assays were repeated independently more than three times. Data are represented as mean $\pm S E M$ in the figures. $P$ values were calculated using the Student's paired t-test.

\section{Results}

SC66 suppressed proliferation in various colon cancer cells by targeting Akt

To investigate how SC66 influences tumor growth, cell viability was detected by CCK- 8 in HCT-116 after $0.5-4 \mu \mathrm{g} / \mathrm{ml} \mathrm{SC66}$ treatment for $24 \mathrm{~h}$. Our results indicated that cell viability decreased significantly with an increasing dose treatment (Fig. 1a), suggesting SC66 inhibited cell proliferation in a dose-dependent manner. SC66, a novel allosteric AKT inhibitor, directly interacts with $\mathrm{AKT}$ and facilitates its deactivation and ubiquitination [7]. To study whether the cytotoxic effects of SC66 were associated with changes in AKT signaling, western blotting analysis was detected after SC66 treatment. As shown in the Fig. 1c, the results suggested that activated Akt was over expressed in HCT-116 and slightly increased the phosphorylation level of AKT after 0.5 and $1 \mu \mathrm{g} / \mathrm{ml} \mathrm{SC66}$ treatment, whereas the phosphorylation level of AKT were decreased significantly at a dose 

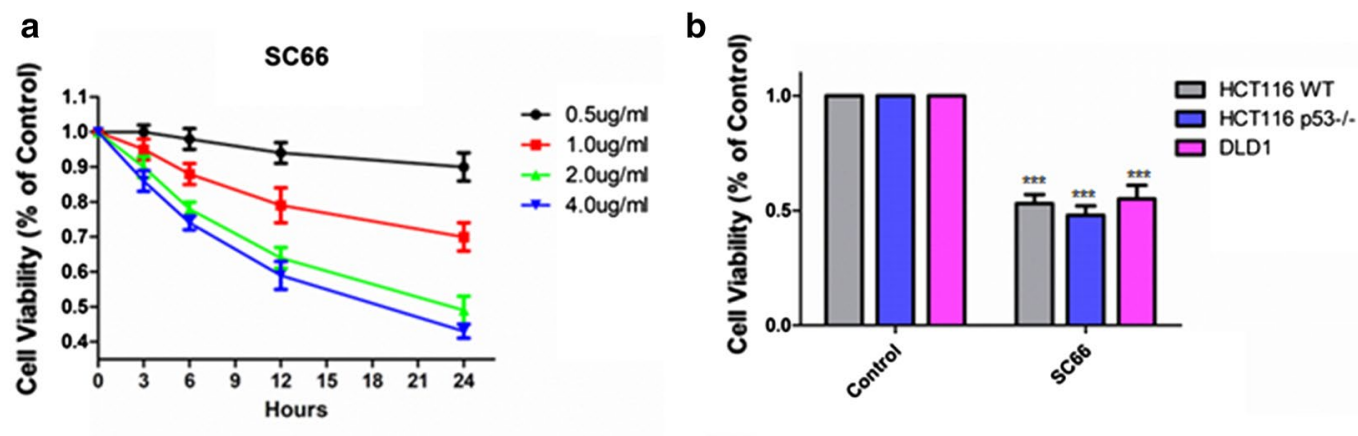

C

d

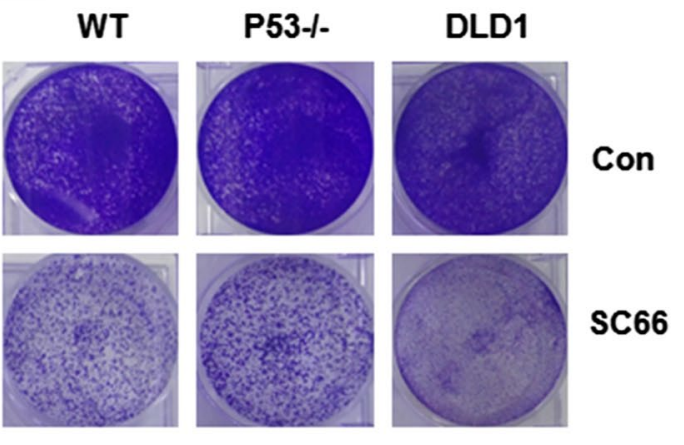

Fig. 1 SC66 inhibited colon cancer cell proliferation in vitro. a Cell viability of HCT-116 was detected using cell counting kit-8 after 0, 0.5, 1,2 or $4 \mathrm{\mu g} / \mathrm{ml} \mathrm{SC66}$ treatment at indicated time. Data represent the mean \pm SEM of four independent experiments. $\mathbf{b}$ Cell viability was analyzed in various colon cancer cells after $2 \mathrm{\mu g} / \mathrm{ml} \mathrm{SC66}$ treatment for $24 \mathrm{~h}$. Data represent the mean \pm SEM of four independent experiments. c Western blotting analysis of P-Akt and Akt expression in HCT-116 WT treated with $2 \mu \mathrm{g} / \mathrm{ml} \mathrm{SC66}$ treatment for $24 \mathrm{~h}$. $\mathbf{d}$ Colony formation was analyzed by crystal violet staining in HCT-116 WT, HCT-1 $16 ~ p 53^{-/-}$and DLD1 cells following $2 \mu \mathrm{g} / \mathrm{ml} \mathrm{SC66}$ treatment for $24 \mathrm{~h}$. Similar results were obtained from three independent experiments

of $2 \mu \mathrm{g} / \mathrm{ml}$ SC66 treatment. At the same time, analysis of total AKT protein levels revealed an obvious decrease at a dose of $2 \mu \mathrm{g} / \mathrm{ml}$ SC66 in HCT-116.

Next, to determine a potential role of p53 in the process, HCT-116 WT, p53-/- and DLD1 (p53 mutant) cells were treated with $2 \mu \mathrm{g} / \mathrm{ml} \mathrm{SC66}$ for $24 \mathrm{~h}$. As a result, each cell line had an obvious decrease in cell viability observed after SC66 treatment, indicating p53 was dispensable (Fig. 1b). Next, as shown in the Fig. 1d, colony formation assay was performed in HCT-116 WT, $\mathrm{p} 53^{-1-}$ and DLD1 cells, which mimics the clonogenic survival of cancer cells in a solid tumor environment. SC66 displayed a potent inhibition of colony forming capacity, which further confirmed the previous results and got a similar conclusion. Taken together, all these data above indicate that SC66 induces AKT phosphorylation and degradation in a p53-independent manner, leading to inhibition of colon cancer cell proliferation.

\section{SC66 induced intrinsic mitochondrial apoptosis in a p53-independent manner}

To determine whether SC66 kill colon cancer cells through initiating the process of apoptosis, FACS analysis was performed in HCT-116 WT, $\mathrm{p} 53^{-1-}$ and DLD1 cells (Fig. 2a). The results indicated that p53 deficiency or p53 mutation had nearly no influence on SC66-induced apoptosis, compared to expressing p53 normally in HCT116 WT. The morphology of apoptosis was investigated by using Hoechst 33342 staining, and similar trends were obtained. Besides, in the HCT-116 cells, Bax activation and cleavage of Caspase 3 were markedly detected (Fig. 2d), meaning SC66 induced apoptosis through the intrinsic mitochondrial pathway. Interestingly, western blotting analysis has shown that SC66 treatment did not cause p53 activation at all (Figs. 1c and 2d), suggesting Akt inactivation was independent of p53 responding to SC66 stimulation. To further confirm whether SC66-triggered Bax activation, Bax oligomerization in mitochondria was also detected (Fig. 2c). In short, these results revealed that SC66 triggers apoptosis in a p53-independent manner.

Targeting Akt activated GSK-3 $\beta$ and down-regulated Bcl-xL To explore the mechanism through which SC66 induce cell apoptosis, western blotting assays were performed. Previous data indicated that AKT may activate a classical down-stream target GSK3 $\beta$. To confirm the modulation of AKT and its down-stream signaling, we evaluated 

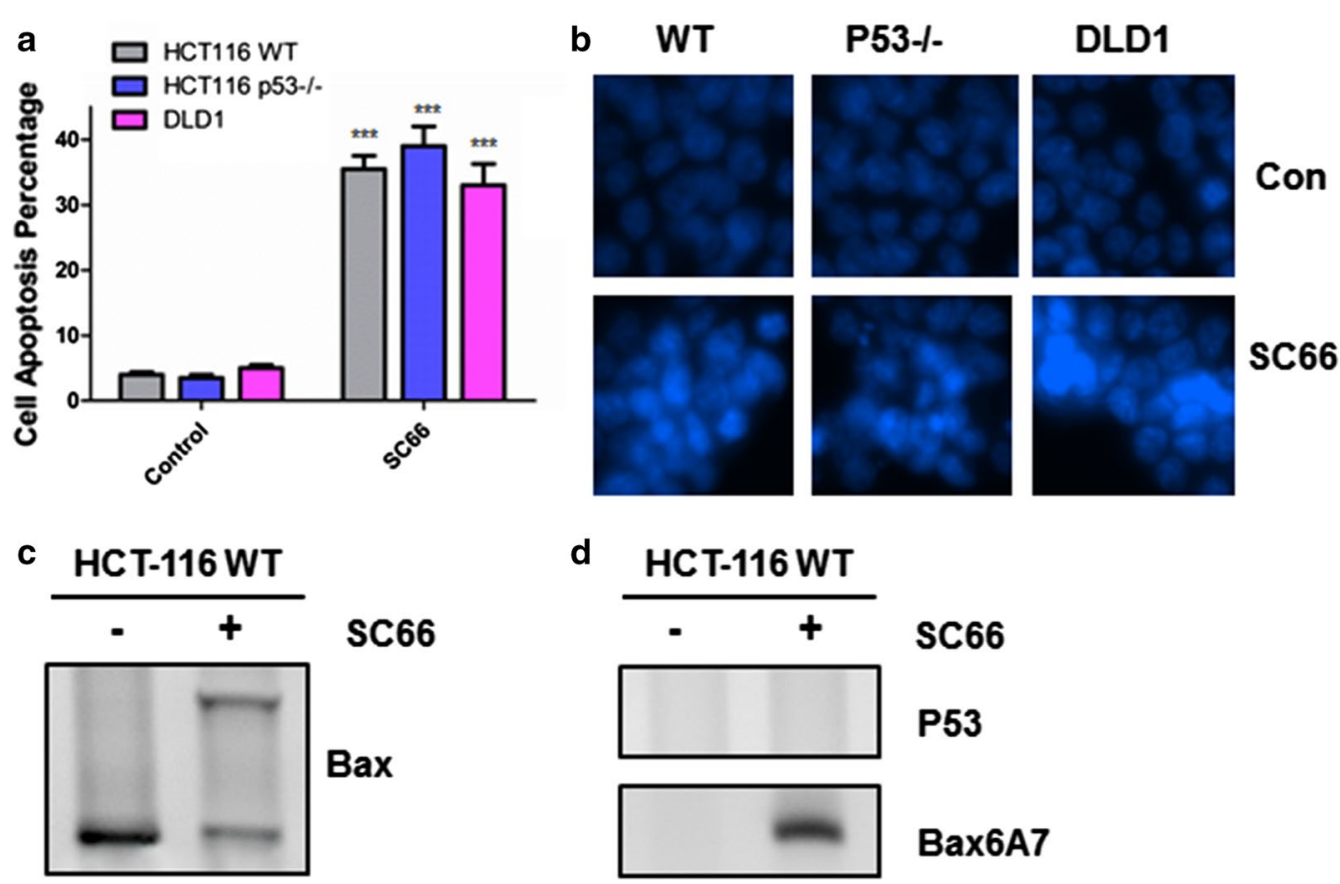

d
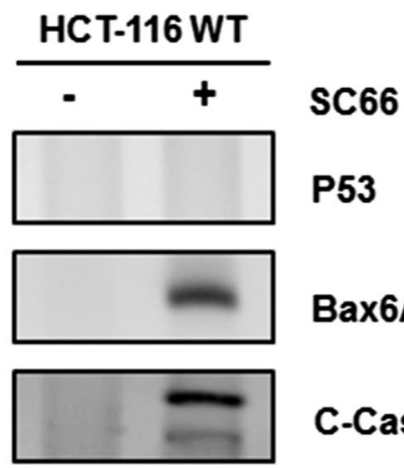

Bax6A7

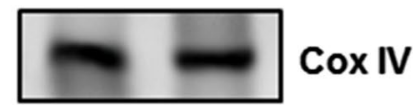

C-Caspase3

\section{Mitochondrial (DSP)}

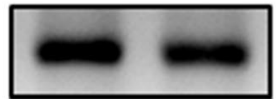

$\beta$-actin

Fig. 2 SC66 triggered cell apoptosis in a p53-independent pathway. a Cell apoptosis was analyzed by fluorescence-activated cell sorting (FACS) analysis after HCT-1 16 WT, HCT-116 p53-l- and DLD1 cells were treated with $2 \mu \mathrm{g} / \mathrm{ml} \mathrm{SC66}$ for $24 \mathrm{~h}$. The percentage of apoptotic cells were calculated from fluorescence activated cell sorting (FACS) analysis. Data represent the mean \pm SD of three independent experiments. ${ }^{* * * P}<0.001$ vs untreated control cells. b Hoechst 33342 morphological examination of apoptosis in HCT-116 WT, HCT-116 p53-/- and DLD1 cells were treated with $2 \mu \mathrm{g} / \mathrm{ml} \mathrm{SC66}$ and incubated for $24 \mathrm{~h}$, then stained with Hoechst 33342. c Bax multimerization in mitochondria fraction was detected by Western blotting after DSP cross-link. d Western blotting show the expression of p53, PUMA, Bax6A7 and cleaved Caspase 3 in HCT-116 with 2 mg/ $\mathrm{ml} \mathrm{SC66}$ for $24 \mathrm{~h}$. Similar results were obtained from three independent experiments

the phosphorylation levels of AKT and GSK-3 $\beta$ proteins. Treatment with $2 \mu \mathrm{g} / \mathrm{ml}$ SC66 reduced the expression of phospho-AKT and total AKT, and subsequently resulted in the dephosphorylation of GSK-3 $\beta$ in HCT116 (Fig. 3a). These data mean AKT blockade leads to the reduction of phospho-GSK-3 $\beta$ level, suggesting SC66 accelerates the activation of GSK-3 $\beta$ through AKT inhibition.

Our previous results have proved that SC66 triggered cell apoptosis through Bax oligomerization and its activation (Fig. 2c, d). As shown in Fig. 3b, other Bcl-2 family members were detected. The expression of pro-apoptosis proteins such as PUMA and Bcl-2 did not alter following SC66 treatment. In contrast, SC66 treatment did reduce $\mathrm{Bcl}-\mathrm{xL}$ protein level obviously and also decrease Mcl-1 protein level slightly. Next, we demonstrated that SC66 activated GSK-3 $\beta /$ Bax and diminished Bcl-xL in other colon cancer cells including RKO and DLD1 cells regardless of the p53 status (Fig. 3c). As a result, AKT was overexpressed in HCT-116 and significantly abolished the SC66-induced decrease of p-AKT (Ser473) and $\mathrm{p}-\mathrm{GSK}-3 \beta$ levels, as well as the increase of Bcl-xL level (Fig. 3d). As shown in Fig. 3c, d, SC66 inhibited Akt phosphorylation and total-Akt expression, however, did not affect the expression of total-GSK-3 $\beta$. These results strongly indicate that Akt inactivation after SC66 treatment activates GSK-3 $\beta / \mathrm{Bax}$, and simultaneously inhibits $\mathrm{Bcl}-\mathrm{xL}$ expression in colon cancer cells regardless of $\mathrm{p} 53$ status.

GSK3 $\beta$ interacted with Bax directly which is indispensable for $\mathrm{BCl}-\mathrm{xL}$ down-regulation and SC66-induced apoptosis Our previous studies have proved that inactivated GSK-3 $\beta$ suppresses Bax translocation via the PI3K/AKT/ GSK-3 $\beta$ axis after LPLI treatment [35]. In this study, to test whether GSK-3 $\beta$ binds to Bax following SC66 
a
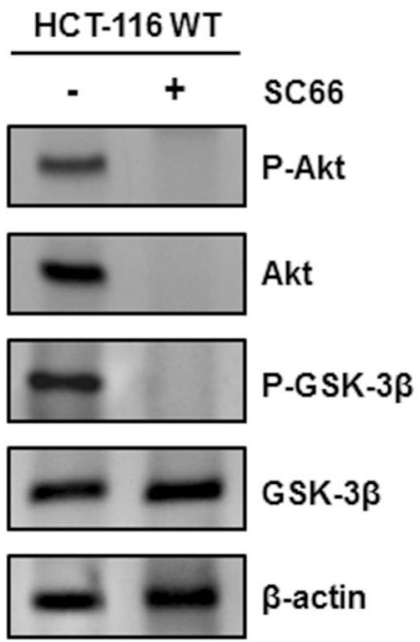

GSK-3 $\beta$

$\beta$-actin

C

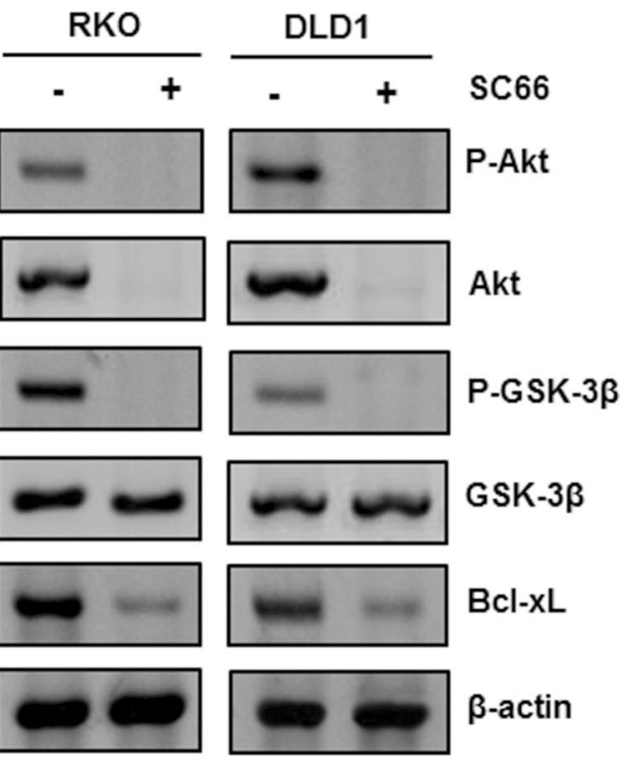

b
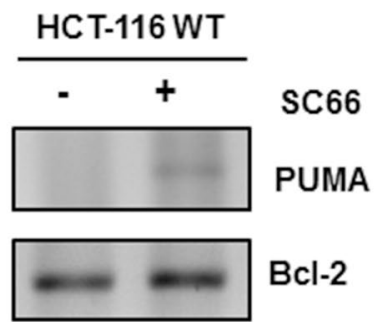

$\mathrm{Bcl}-2$
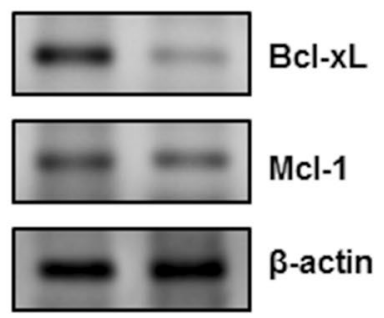

d

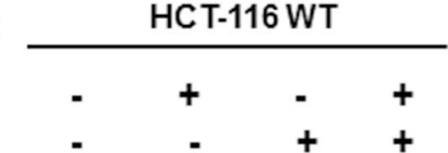

SC66

Active-

Akt

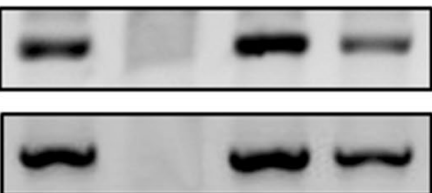

P-Akt

Akt

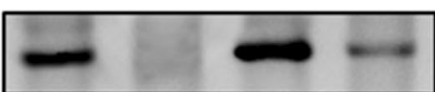

P-GSK-3 $\beta$

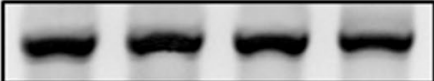

GSK-3 $\beta$

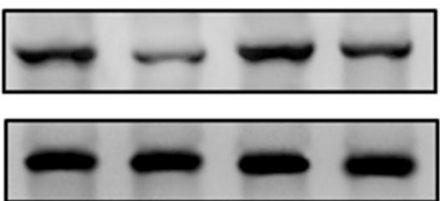

$\mathrm{Bcl}-\mathrm{xL}$

$\beta$-actin

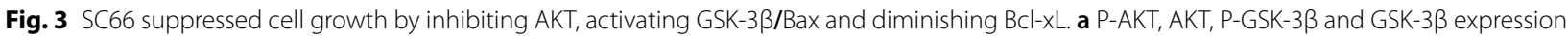
were analyzed by western blotting in HCT-116 at 30 min after $2 \mu \mathrm{g} / \mathrm{ml} \mathrm{SC66}$ treatment. b Puma, BCl-2, BCl-xL and Mcl-1 were detected in HCT-116 cells after SC66 for 24 h. c AKT, GSK-3 $\beta$ and Bcl-xL, expressions were analyzed by western blotting in RKO and DLD1 after $2 \mu \mathrm{g} / \mathrm{ml}$ SC66 treatment

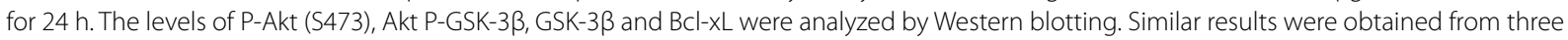
independent experiments. $\mathbf{d}$ HCT-116 WT were transfected with either empty vector or a constitutively-active Akt expression constructs for 48 h, then $2 \mu \mathrm{g} / \mathrm{ml} \mathrm{SC66}$ was added into the culture medium and kept for $12 \mathrm{~h}$, finally cells were harvested to detect the results. The levels of P-Akt (S473), Akt P-GSK-3 $\beta$, GSK-3 $\beta$ and BCl-xL were analyzed by Western blotting. Similar results were obtained from three independent experiments

treatment, the endogenous GSK-3 $\beta$ and Bax complex was further confirmed by reciprocal immunoprecipitation (Fig. 4a, b), meaning GSK-3 $\beta$ binds to Bax directly after $2 \mu \mathrm{g} / \mathrm{ml}$ SC66 treatment. To further confirm whether GSK-3 $\beta$ was indispensable in this process, GSK-3 $\beta$ was knocked down by using shRNA in HCT-116. Next, the activated/pro-apoptotic form of Bax was detected by using a conformation-specific anti-Bax monoclonal antibody (6A7). As shown in the Fig. 4c, knocking down GSK-3 $\beta$ effectively eliminated SC66-triggered Bax activation and Bcl-xL diminution in the presence of SC66.

Furthermore, the results of Fig. 4c, d indicated that GSK-3 $\beta$ knockdown and overexpression is effective. Taken together, the results demonstrated over-expression of constitutively active GSK-3 $\beta$ in HCT-116 markedly enhanced SC66-induced the activation of Bax, as well as 


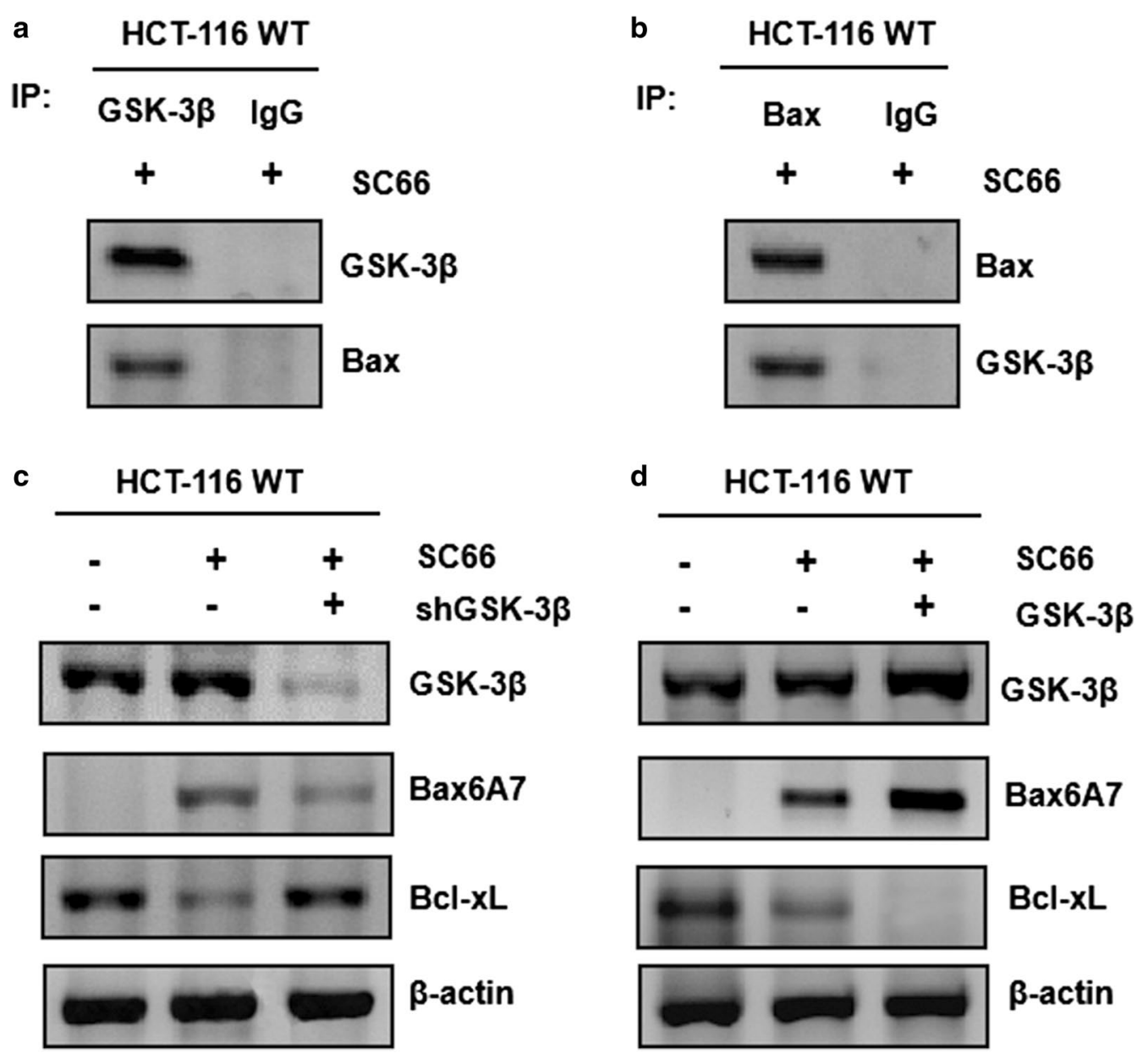

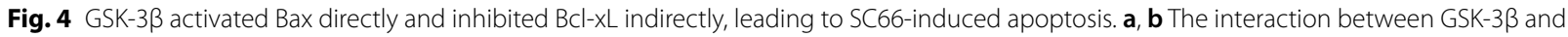
Bax increased after SC66 treatment. Co-immunoprecipitation with an anti-GSK-3 $\beta$ antibody or anti-Bax antibody was used to pull down GSK-3 $\beta$ or Bax. a Western blotting for Bax showed the amount of Bax binding to GSK-3 $\beta$. $\mathbf{b}$ Western blotting for GSK-3 $\beta$ showed the amount of GSK-3 $\beta$

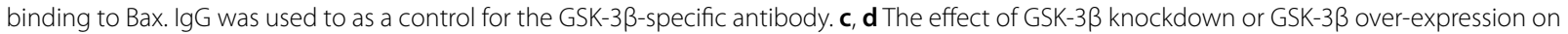

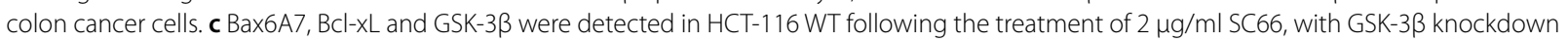
or not. Similar results were obtained from three independent experiments. $\mathbf{d}$ HCT116 WT were transfected with either empty vector or a

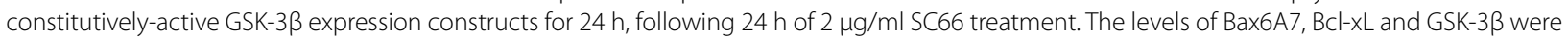
analyzed by Western blotting. Similar results were obtained from three independent experiments

the diminution of Bcl-xL, suggesting GSK-3 $\beta$ also activates Bax translocation indirectly by inhibiting Bcl-xL and subsequently modulating the interaction between Bax and Bcl-xL after SC66 stimulation. Together, these data show that GSK-3 $\beta$ activates Bax directly and inhibits $\mathrm{Bcl}-\mathrm{xL}$ simultaneously through the mitochondrial pathway, during which GSK-3 $\beta$ is necessary for the proapoptotic effect of SC66 in colon cancer cells.

\section{SC66 induced apoptosis via AKT/GSK-3 $\beta / B a x$ axis}

To explore the essential role of Bax activation in GSK$3 \beta$-mediated apoptosis, wild-type or $\mathrm{Bax}^{-1-}$, HCT-116 cells were treated with SC66 for $24 \mathrm{~h}$. Meanwhile, as a direct upstream target of Bax, GSK-3 $\beta$ was deleted by shGSK- $3 \beta$ in HCT-116 cell to evaluate its function. As shown in Fig. 5a, colony formation assay was performed. As a result, GSK-3 $\beta$ deletion evidently induced cell growth inhibition, while Bax deficiency almost completely inhibited. Cell viability detection gave us the similar trends (Fig. 5b). Next, the morphology of apoptosis was performed by using Hoechst 33324 staining (Fig. 5c). The results demonstrated that both GSK- $3 \beta$ deletion and Bax deficiency played a significant role in suppressing cell apoptosis. Flow cytometry experiments were also performed, which further confirmed the previous results and got a similar conclusion (Fig. 5d). In short, these 


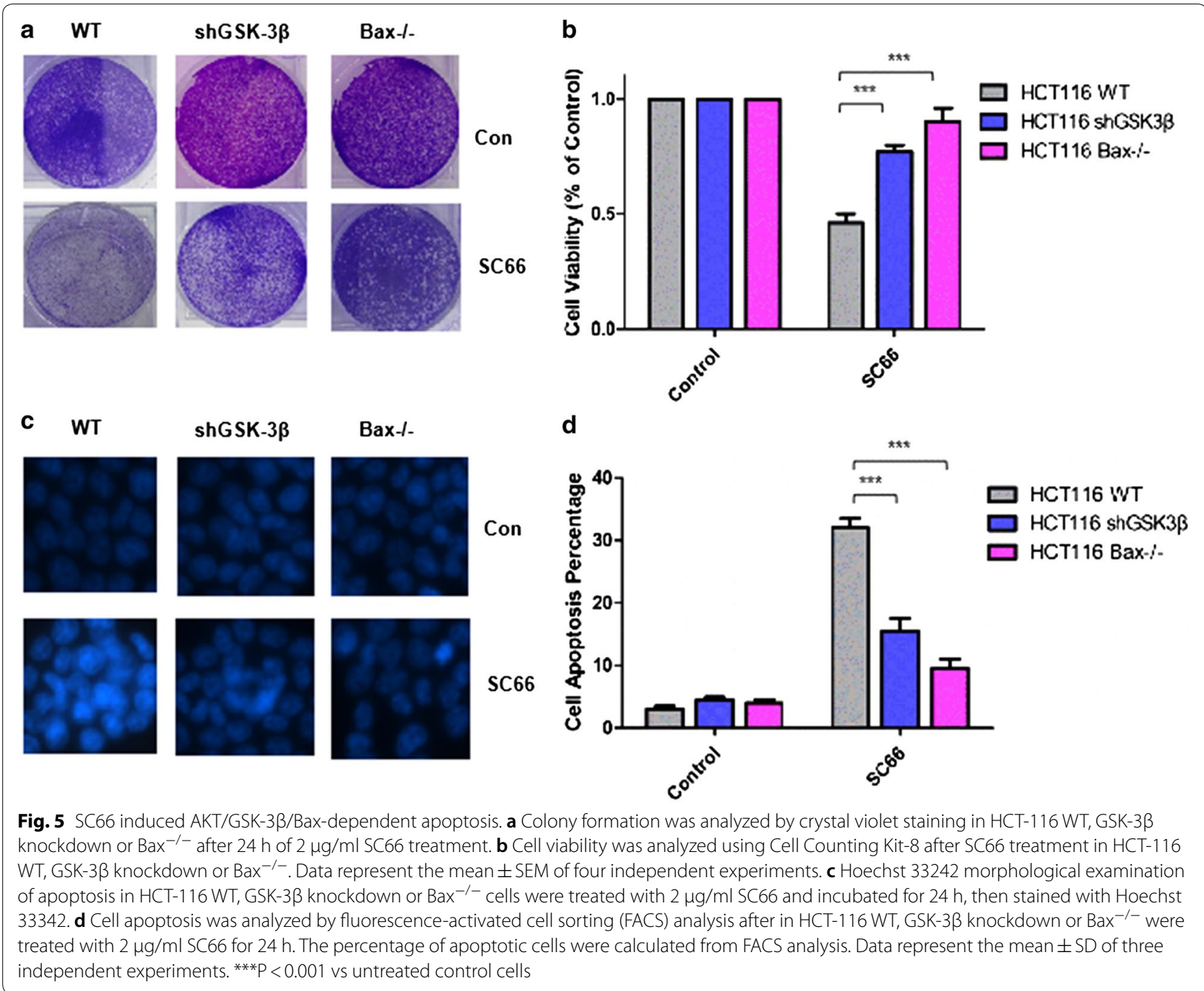

results reveal that $\mathrm{AKT}$ inhibition promotes the process of SC66-induced cell apoptosis through GSK-3 $\beta /$ Baxdependent pathway.

\section{SC66 suppressed tumor growth in vivo}

To demonstrate the effectiveness in vivo of SC66 on CRC, we established subcutaneous tumors using HCT-116 WT cells in xenograft mice models. When solid tumors became palpable, at a size of about $150 \mathrm{~mm}^{3}$, nude mice were randomly divided into two groups with 3 mice in each group. The treated group received SC66 at $25 \mathrm{mg} / \mathrm{kg}$ by i.p. injection every other 3 days for 15 days (PBS was used as the untreated control). As observed in Fig. 6a, the growth of parental tumor was significantly inhibited by about $65 \%$ following SC66 stimulation, meaning a satisfactory level of drug cytotoxicity. Quantitative analysis on the body weight and volume of tumors obtained similar trends (Fig. 6b, c). The levels of P-Akt, total-Akt,
P-GSK-3 $\beta$, total-GSK-3 $\beta$ and Bcl-xL were analyzed and detected in representative tumors' samples. The Western blotting analysis were also performed to further confirm the previous results and got a similar conclusion (Fig. 6d). All these data suggested SC66 displayed a significant tumor growth reduction.

\section{Discussion}

Colorectal cancer remains the third most commonly diagnosed malignancies in the worldwide, which has been estimated about 1.2 million new cases and almost 600,000 deaths annually [36, 37]. Resistance to conventional systemic frontline therapies is a big hurdle in treating colon cancer and reducing serious side-effects due to lack of specificity such as 5-FU, leucovorin, oxaliplatin and irinotecan [38-40]. As we all know, the aberrant activation of $\mathrm{AKT} / \mathrm{PKB}$ pathway in a variety of cancers including colon cancer is crucial in the proliferation, 
a

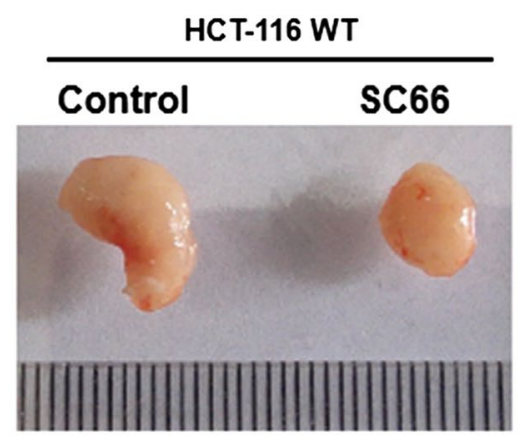

C

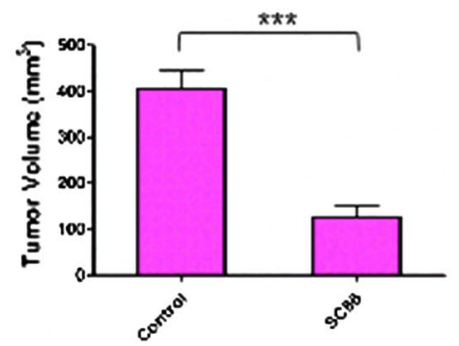

d

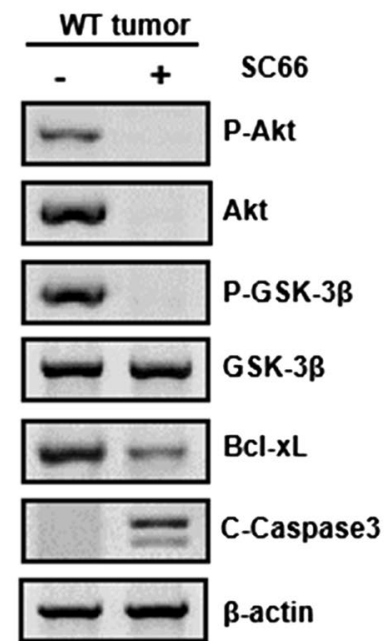

b

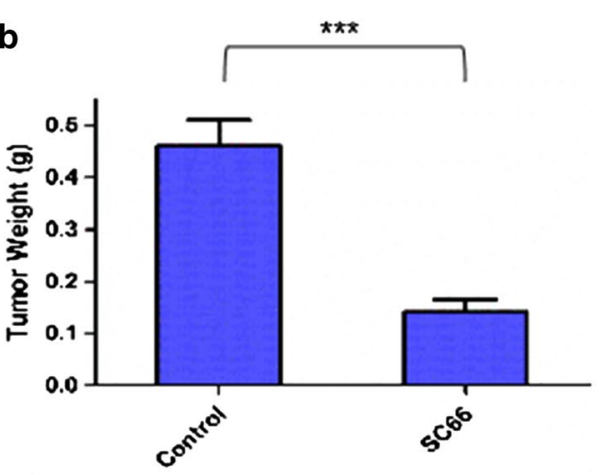

e

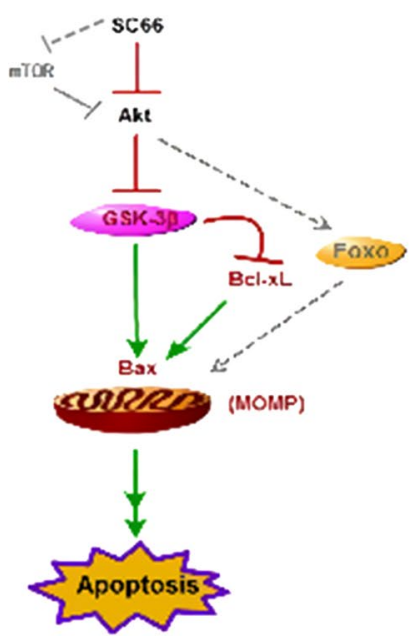

Fig. 6 SC66 exhibited the anti-tumor effects in vivo. Nude mice were injected s.c. with $1 \times 10^{6}$ HCT-116. Once the tumor was measurable, mice were treated daily with SC66 at $25 \mathrm{mg} / \mathrm{kg}$ by i.p. injection every other 3 days for 15 days. a Representative tumors at the end of the experiment. (the most significant group of three). b, c Tumor weight (b) and tumor volume at (c) indicated time points after treatment was calculated ( $n=3$ per group). Statistical significance is indicated for the comparison of SC66-treated tumor. Data represent the mean \pm SEM of four independent experiments. ${ }^{* *} \mathrm{P}<0.001 \mathrm{vs}$. WT. $\mathbf{d}$ The levels of P-Akt, total-Akt, P-GSK-3 $\beta$, total-GSK-3 $\beta$ and Bcl-xL were analyzed in representative tumors by Western blotting analysis. Similar results were obtained from three independent experiments. e Schematic representation of SC66 induced apoptotic pathway

resistance to apoptosis, metabolism and angiogenesis. AKT mediates cell survival and death by directly and indirectly phosphorylating pro-apoptotic Bcl-2 family proteins or regulating transcriptional factors (for example, FoxO3a, NF-кB, p73 and p53) [15, 19, 41-43]. Therefore, novel therapeutic strategies are needed to advance for cancer patients, suggesting designing of new drugs targeting alternative AKT signaling may be more attractive and appeal for therapeutic intervention.

Historically, several available molecules inhibiting AKT are categorized into three groups including ATP-competitive inhibitors, phosphatidylinositol analogs, and allosteric inhibitors [17]. Novel agents such as NVP-BEZ235 and MK-2206, are now in preclinical development [4447]. More recently, SC66 is a potent and highly selective allosteric pan AKT inhibitor, which facilitates AKT ubiquitination and further inhibits glucose uptake in vitro and in vivo. Recent studies have reported that SC66 has shown a strong anti-tumor activity, including hepatocellular carcinoma and cervical cancer with PIK3CA R88Q and PTEN R233* mutation $[6,8]$. However, the antitumor effects of SC66 and the underlying mechanism in colon cancer still remain to be elucidated.

In the current study, we investigated the potential antitumor activity of SC66 on colon cancer cell lines, showing that colon cancer growth was effectively suppressed after SC66 simulation (Figs. 1, 2, 5 and 6). Next, we further studied the precise mechanism of SC66 inducedapoptosis. Using multiple cell lines including WT, p53 mutant or knockout cells, we demonstrated that SC66 induced apoptosis through p53-independent pathway for the first time (Figs. 1, 2 and 3).

Previous reports from our laboratory have demonstrated that low-power laser irradiation exerts protective 
effects in preventing cell apoptosis by activating AKT and inactivating GSK-3 $\beta$ [35]. Current studies have demonstrated oligo-porphyran offers a neuroprotective treatment for Parkinson's disease via PI3K/Akt/GSK-3 $\beta$ pathway, with changes in the $\mathrm{Bax} / \mathrm{Bcl}-2$ ratio [48]. However, some studies showed that activated GSK-3 $\beta$ promoted Bax activation in a p53-dependent pathway [49]. Our results showed that AKT activity was highly inhibited in various colon cancer cell lines after SC66 treatment, suggesting AKT signal is independent of p53. The canonical pathway of GSK-3 $\beta$ activation is mediated by NF- $\kappa \mathrm{B}$ phosphorylation, for example, in response to sorafenib [42]. Notably, we confirmed SC66 showed greatly suppression of AKT activity and induced apoptosis through the significant factor GSK-3 $\beta$, but not depend on the important factor such as p53 (Figs. 2,3).

AKT inhibition led to activation of GSK-3 $\beta$, that promoted Bax translocation by directly binding to Bax, simultaneously decreasing $\mathrm{Bcl}-\mathrm{xL}$, and subsequently triggering the mitochondrial apoptosis (Figs. 3, 4, 5). In addition, GSK-3 $\beta /$ Bax axis is indispensable for using SC66 to treat colon cancer (Figs. 4, 5, 6). The influence of Bax deficiency on SC66 induced-apoptosis is inferior to that of GSK-3 $\beta$ deletion in HCT-116. These results above indicated that SC66 regulated cell survival and apoptosis via the AKT/GSK-3 $\beta /$ Bax pathway, which is distinct from previous reports involved the PI3K/Akt/mTOR or PI3K/ PKB/Egr-1 pathway $[6,50]$.

Research has identified that SC66 interferes with the PH domain binding to PIP3 and directly enhances Akt ubiquitination and its deactivation in both HeLa and HEK293T cells [7]. Recent report claims that SC66 had significant anti-tumor effects on hepatocellular carcinoma cells through producing ROS, subsequently inducing anoikis-mediated cell death and inhibiting the AKT signaling pathway [8]. And the novel Akt inhibitor SC66 directly deactivated Akt and facilitated the activation of Foxo, eventually triggering apoptosis. Some studies also indicated that SC66 effectively inhibited the phosphorylation levels of AKT through disruption of mTOR signaling, and therefore contributes to decrease the expressions of p-GSK-3 $\beta$ and p-FOXO1 in human cervical cancer [6]. Further study in this area may be instructive in different Akt inhibitors, dual PI3K/mTOR inhibitors or other multi-kinase inhibitors.

Previous studies also demonstrated Akt inhibition by pazopanib, ipatasertib or NVP-BEZ235 induced PUMAdependent apoptosis in colon cancer through activating FoxO3a transcriptionally [32, 33, 51]. Besides, the results indicated that $\mathrm{Mcl}$ may also play some roles while $\mathrm{Bax}$ and $\mathrm{Bcl}-\mathrm{xL}$ seem to be the key regulators of mediating cell apoptosis (Fig. 3). A recent study indicated that regorafenib induced colon cancer cell apoptosis via GSK-3 $\beta /$ Mcl-1 axis [52]. Therefore, it seems a link between GSK-3 $\beta$ and Mcl is complicated, which is worth to be further studied.

In conclusion, we provided the first evidence that SC66 exerts its antitumor effects through GSK-3 $\beta /$ Bax pathway through AKT inhibition and initiates apoptosis through the mitochondrial pathway, which is p53-independent. GSK-3 $\beta$ deletion or Bax deficiency abrogated SC66induced apoptosis and promoted colon cell survival. Together with the data from xenograft mice in vivo, we highlight the novel AKT inhibitor SC66 may function as a promising and potential therapeutic drug for colon cancer treatment, providing the rationale for clinical application in the future.

\section{Conclusion}

Previous reports from our laboratory have shown that low-power laser irradiation (LPLI) inactivates GSK-3 $\beta$ and inhibits apoptosis via the PI3K/Akt pathway [35]. In this study, the anti-tumor effect of SC66 in colon cancer and molecular mechanism behind were clarified. Our results demonstrated that the novel small molecule AKT inhibitor SC66 suppressed colon cancer cell growth through the AKT/GSK-3 $\beta /$ Bax axis irrespective of p53 status. GSK-3 $\beta$ deletion resulted in resistance to SC66induced apoptosis, which is through the mitochondrial pathway. SC66 also suppressed tumor growth in vivo (xenograft mice). Together, these results indicated the therapeutic response to SC66 is through Akt/GSK-3 $\beta$ / Bax axis, which served GSK-3 $\beta$ as a potential biomarker for colon cancer therapy.

\section{Abbreviations}

GSK-3 $\beta$ : glycogen synthase kinase-3 $\beta$; Bax: BCl-2-associated X protein; CRC : colorectal cancer; CCK-8: cell counting kit-8; IHC: immunohistochemistry; FACS: fluorescence activated cell sorting.

\section{Authors' contributions \\ YL: study conception and data acquisition and interpretation and draft the manuscript; YH, JD and NL: analyses and collection; SP: data acquisition and interpretation; JW, FW and YZ: study design and data supervision and contributed to manuscript review. All authors read and approved the final manuscript.}

\section{Author details}

${ }^{1}$ Department of Health Management, The Third Xiangya Hospital, Central South University, College of Biology, Hunan University, No. 1, Denggao Road, Changsha, China. ${ }^{2}$ Department of Gastroenterology, The Tenth People's Hospital of Shanghai, Tongji University, Shanghai, China. ${ }^{3}$ Department of Emergency Surgery, The Second Military Medical University, Shanghai, China.

${ }^{4}$ Shenzhen Institute, Hunan University, Shenzhen, China.

\section{Acknowledgements}

We would like express sincere appreciation to the reviewers for critical comments on this article.

Competing interests

The authors declare that they have no competing interests. 


\section{Availability of data and materials}

All data generated or analyzed during this current study are available.

\section{Consent for publication}

Not applicable.

\section{Ethics approval and consent to participate}

Not applicable.

\section{Funding}

We would like to thank the support of the support of the National Natural Science Foundation of China (31801140, 31701132), the Basic Research Program of Shenzhen Municipal Science and Technology Innovation Committee (JCYJ20160530192802733), the Fundamental Research Funds for the Central Universities (No. 531107040909, No. 14700-502044001), and the start funds from College of Biology, Hunan University.

\section{Publisher's Note}

Springer Nature remains neutral with regard to jurisdictional claims in published maps and institutional affiliations.

Received: 28 December 2018 Accepted: 25 April 2019

Published online: 09 May 2019

\section{References}

1. Chester JD, Joel SP, Cheeseman SL, Hall GD, Braun MS, Perry J, Davis T, Button CJ, Seymour MT. Phase I and pharmacokinetic study of intravenous irinotecan plus oral ciclosporin in patients with fuorouracilrefractory metastatic colon cancer. J Clin Oncol. 2003;21(6):1125-32.

2. Kelly H, Goldberg RM. Systemic therapy for metastatic colorectal cancer: current options, current evidence. J Clin Oncol. 2005;23(20):4553-60.

3. Kim EJ, Kang GJ, Kang Jl, Boo HJ, Hyun JW, Koh YS, Chang WY, Kim YR, Kwon JM, Maeng YH, et al. Over-activation of AKT signaling leading to 5-fluorouracil resistance in SNU-C5 5-FU cells. Oncotarget. 2018;9(28):19911-28.

4. Linnekamp JF, Wang X, Medema JP, Vermeulen L. Colorectal cancer heterogeneity and targeted therapy: a case for molecular disease subtypes. Cancer Res. 2015;75(2):245-9.

5. Adlard JW, Richman SD, Seymour MT, Quirke P. Prediction of the response of colorectal cancer to systemic therapy. Lancet Oncol. 2002;3(2):75-82.

6. Rashmi R, DeSelm C, Helms C, Bowcock A, Rogers BE, Rader JL, Grigsby PW, Schwarz JK. AKT inhibitors promote cell death in cervical cancer through disruption of mTOR signaling and glucose uptake. PLoS ONE. 2014;9(4):e92948

7. Jo H, Lo PK, Li Y, Loison F, Green S, Wang J, Silberstein LE, Ye K, Chen H, Luo HR. Deactivation of Akt by a small molecule inhibitor targeting pleckstrin homology domain and facilitating Akt ubiquitination. Proc Natl Acad Sci USA. 2011;108(16):6486-91.

8. Cusimano A, Puleio R, D'Alessandro N, Loria GR, McCubrey JA, Montalto G, Cervello M. Cytotoxic activity of the novel small molecule AKT inhibitor SC66 in hepatocellular carcinoma cells. Oncotarget. 2015;6(3):1707-22.

9. Choy YY, Fraga M, Mackenzie GG, Waterhouse AL, Cremonini E, Oteiza $\mathrm{PI}$. The PI3K/Akt pathway is involved in procyanidin-mediated suppression of human colorectal cancer cell growth. Mol Carcinog. 2016;55(12):2196-209.

10. Engelman JA. Targeting PI3K signalling in cancer: opportunities, challenges and limitations. Nat Rev Cancer. 2009;9(8):550-62.

11. Johnson SM, Gulhati P, Rampy BA, Han Y, Rychahou PG, Doan HQ, Weiss HL, Evers BM. Novel expression patterns of PI3K/Akt/mTOR signaling pathway components in colorectal cancer. J Am Coll Surg. 2010;210(5):767-76.

12. Tenbaum SP, Ordonez-Moran P, Puig I, Chicote I, Arques O, Landolfi S, Fernandez Y, Herance JR, Gispert JD, Mendizabal L, et al. beta-catenin confers resistance to $\mathrm{PI} I \mathrm{~K}$ and $\mathrm{AKT}$ inhibitors and subverts FOXO3a to promote metastasis in colon cancer. Nat Med. 2012;18(6):892-901.
13. Brunet A, Bonni A, Zigmond MJ, Lin MZ, Juo P, Hu LS, Anderson MJ, Arden KC, Blenis J, Greenberg ME. Akt promotes cell survival by phosphorylating and inhibiting a forkhead transcription factor. Cell. 1999;96(6):857-68.

14. Dudek H, Datta SR, Franke TF, Birnbaum MJ, Yao R, Cooper GM, Segal RA, Kaplan DR, Greenberg ME. Regulation of neuronal survival by the serinethreonine protein kinase Akt. Science. 1997;275(5300):661-5.

15. Datta SR, Dudek H, Tao X, Masters S, Fu H, Gotoh Y, Greenberg ME. Akt phosphorylation of BAD couples survival signals to the cell-intrinsic death machinery. Cell. 1997;91(2):231-41.

16. Alessi DR, Andjelkovic M, Caudwell B, Cron P, Morrice N, Cohen P, Hemmings BA. Mechanism of activation of protein kinase $B$ by insulin and IGF-1. EMBO J. 1996;15(23):6541-51.

17. Manning BD, Toker A. AKT/PKB signaling: navigating the network. Cell. 2017;169(3):381-405

18. Yamaguchi A, Tamatani M, Matsuzaki H, Namikawa K, Kiyama H, Vitek MP, Mitsuda N, Tohyama M. Akt activation protects hippocampal neurons from apoptosis by inhibiting transcriptional activity of p53. J Biol Chem. 2001;276(7):5256-64

19. Ozes ON, Mayo LD, Gustin JA, Pfeffer SR, Pfeffer LM, Donner DB. NFkappaB activation by tumour necrosis factor requires the Akt serinethreonine kinase. Nature. 1999;401(6748):82-5.

20. Santo EE, Stroeken P, Sluis PV, Koster J, Versteeg R, Westerhout EM. FOXO3a is a major target of inactivation by PI3K/AKT signaling in aggressive neuroblastoma. Cancer Res. 2013;73(7):2189-98.

21. Rokudai S, Fujita N, Hashimoto Y, Tsuruo T. Cleavage and inactivation of antiapoptotic Akt Pkb by caspases during apoptosis. J Cell Physiol. 2000;182(2):290-6.

22. Pal D, Tyagi A, Chandrasekaran B, Alattasi H, Ankem MK, Sharma AK, Damodaran C. Suppression of Notch1 and AKT mediated epithelial to mesenchymal transition by Verrucarin J in metastatic colon cancer. Cell Death Dis. 2018;9(8):798.

23. Cross DA, Alessi DR, Cohen P, Andjelkovich M, Hemmings BA. Inhibition of glycogen synthase kinase-3 by insulin mediated by protein kinase B. Nature. 1995;378(6559):785-9.

24. Bijur GN, De Sarno P, Jope RS. Glycogen synthase kinase-3beta facilitates staurosporine- and heat shock-induced apoptosis protection by lithium. J Biol Chem. 2000;275(11):7583-90.

25. Cross TG, Scheel-Toellner D, Henriquez NV, Deacon E, Salmon M, Lord $J M$. Serine/threonine protein kinases and apoptosis. Exp Cell Res. 2000;256(1):34-41.

26. Linseman DA, Butts BD, Precht TA, Phelps RA, Le SS, Laessig TA, Bouchard RJ, Florez-McClure ML, Heidenreich KA. Glycogen synthase kinase-3beta phosphorylates Bax and promotes its mitochondrial localization during neuronal apoptosis. J Neurosci. 2004;24(44):9993-10002.

27. Charvet C, Wissler M, Brauns-Schubert P, Wang SJ, Tang Y, Sigloch FC, Mellert $\mathrm{H}$, Brandenburg M, Lindner SE, Breit B, et al. Phosphorylation of Tip60 by GSK-3 determines the induction of PUMA and apoptosis by p53. Mol Cell. 2011;42(5):584-96.

28. Nagini S, Sophia J, Mishra R. Glycogen synthase kinases: moonlighting proteins with theranostic potential in cancer. Semin Cancer Biol. 2018. https://doi.org/10.1016/j.semcancer.2017.12.010.

29. Watcharasit P, Bijur GN, Song L, Zhu J, Chen X, Jope RS. Glycogen synthase kinase-3beta (GSK3beta) binds to and promotes the actions of p53. J Biol Chem. 2003;278(49):48872-9.

30. Zhang Y, Xing D, Liu L. PUMA promotes Bax translocation by both directly interacting with Bax and by competitive binding to Bcl-X L during UVinduced apoptosis. Mol Biol Cell. 2009;20(13):3077-87.

31. Tong J, Zheng X, Tan X, Fletcher R, Nikolovska-Coleska Z, Yu J, Zhang L. MCl-1 phosphorylation without degradation mediates sensitivity to HDAC inhibitors by liberating BH3-only proteins. Cancer Res. 2018;78(16):4704-15.

32. Wang $H$, Zhang L, Yang $X$, Jin $Y$, Pei S, Zhang D, Zhang H, Zhou B, Zhang $Y$, Lin D. PUMA mediates the combinational therapy of 5-FU and NVPBEZ235 in colon cancer. Oncotarget. 2015;6(16):14385-98.

33. Zhang L, Wang H, Li W, Zhong J, Yu R, Huang X, Wang H, Tan Z, Wang J, Zhang Y. Pazopanib, a novel multi-kinase inhibitor, shows potent antitumor activity in colon cancer through PUMA-mediated apoptosis. Oncotarget. 2017;8(2):3289-303.

34. Billen LP, Kokoski CL, Lovell JF, Leber B, Andrews DW. BCl-XL inhibits membrane permeabilization by competing with Bax. PLoS Biol. 2008;6(6):e147. 
35. Zhang L, Zhang Y, Xing D. LPLI inhibits apoptosis upstream of Bax translocation via a GSK-3beta-inactivation mechanism. J Cell Physiol. 2010;224(1):218-28.

36. Brenner $\mathrm{H}$, Kloor M, Pox CP. Colorectal cancer. Lancet. 2014;383(9927):1490-502.

37. Siegel RL, Miller KD, Fedewa SA, Ahnen DJ, Meester RGS, Barzi A, Jemal A. Colorectal cancer statistics, 2017. CA Cancer J Clin. 2017:67(3):177-93.

38. Sobrero A, Lonardi S, Rosati G, Di Bartolomeo M, Ronzoni M, Pella N, Scartozzi M, Banzi M, Zampino MG, Pasini F, et al. FOLFOX or CAPOX in stage II to III colon cancer: efficacy results of the Italian three or six colon adjuvant trial. J Clin Oncol. 2018;36(15):1478-85.

39. Grassilli E, Narloch R, Federzoni E, lanzano L, Pisano F, Giovannoni R, Romano G, Masiero L, Leone BE, Bonin S, et al. Inhibition of GSK3B bypass drug resistance of p53-null colon carcinomas by enabling necroptosis in response to chemotherapy. Clin Cancer Res. 2013;19(14):3820-31.

40. Iveson TJ, Kerr RS, Saunders MP, Cassidy J, Hollander NH, Tabernero J, Haydon A, Glimelius B, Harkin A, Allan K, et al. 3 versus 6 months of adjuvant oxaliplatin-fluoropyrimidine combination therapy for colorectal cancer (SCOT): an international, randomised, phase 3, non-inferiority trial. Lancet Oncol. 2018;19(4):562-78.

41. Yang S, Zhu Z, Zhang X, Zhang N, Yao Z. Idelalisib induces PUMA-dependent apoptosis in colon cancer cells. Oncotarget. 2017;8(4):6102-13.

42. Dudgeon C, Peng R, Wang P, Sebastiani A, Yu J, Zhang L. Inhibiting oncogenic signaling by sorafenib activates PUMA via GSK3 $\beta$ and NF-KB to suppress tumor cell growth. Oncogene. 2012;31(46):4848-58.

43. Tao Y, Liu Z, Hou Y, Wang S, Liu S, Jiang Y, Tan D, Ge Q, Li C, Hu Y, et al. Alternative NF-kappaB signaling promotes colorectal tumorigenesis through transcriptionally upregulating Bcl-3. Oncogene. 2018;37(44):5887-900.

44. Hirai H, Sootome H, Nakatsuru Y, Miyama K, Taguchi S, Tsujioka K, Ueno Y, Hatch H, Majumder PK, Pan BS, et al. MK-2206, an allosteric Akt inhibitor, enhances antitumor efficacy by standard chemotherapeutic agents or molecular targeted drugs in vitro and in vivo. Mol Cancer Ther. 2010;9(7):1956-67.
45. Jonasch E, Hasanov E, Corn PG, Moss T, Shaw KR, Stovall S, Marcott V, Gan B, Bird S, Wang X, et al. A randomized phase 2 study of MK-2206 versus everolimus in refractory renal cell carcinoma. Ann Oncol. 2017;28(4):804-8.

46. Roper J, Richardson MP, Wang WV, Richard LG, Chen W, Coffee EM, Sinnamon MJ, Lee L, Chen PC, Bronson RT, et al. The dual PI3K/mTOR inhibitor NVP-BEZ235 induces tumor regression in a genetically engineered mouse model of PIK3CA wild-type colorectal cancer. PLoS ONE. 2011:6(9):e25132.

47. Maira SM, Stauffer F, Brueggen J, Furet P, Schnell C, Fritsch C, Brachmann S, Chene P, De Pover A, Schoemaker K, et al. Identification and characterization of NVP-BEZ235, a new orally available dual phosphatidylinositol 3-kinase/mammalian target of rapamycin inhibitor with potent in vivo antitumor activity. Mol Cancer Ther. 2008;7(7):1851-63.

48. Liu Y, Geng L, Zhang J, Wang J, Zhang Q, Duan D, Zhang Q. Oligoporphyran ameliorates neurobehavioral deficits in parkinsonian mice by regulating the PI3K/Akt/BCl-2 pathway. Mar Drugs. 2018;16(3):82.

49. Tan J, Zhuang L, Leong HS, lyer NG, Liu ET, Yu Q. Pharmacologic modulation of glycogen synthase kinase-3beta promotes p53-dependent apoptosis through a direct Bax-mediated mitochondrial pathway in colorectal cancer cells. Cancer Res. 2005;65(19):9012-20.

50. Youreva V, Srivastava AK. Early growth response protein-1 expression by insulin-like growth factor-1 requires ROS-dependent activation of ERK1/2 and PKB pathways in vascular smooth muscle cells. J Cell Biochem. 2016;117(1):152-62

51. Sun L, Huang Y, Liu Y, Zhao Y, He X, Zhang L, Wang F, Zhang Y. Ipatasertib, a novel Akt inhibitor, induces transcription factor FoxO3a and NFkappaB directly regulates PUMA-dependent apoptosis. Cell Death Dis. 2018;9(9):911

52. Tong JS, Wang P, Tan S, Chen DS, Nikolovska-Coleska Z, Zou FD, Yu J, Zhang L. Mcl-1 degradation is required for targeted therapeutics to eradicate colon cancer cells. Cancer Res. 2017;77(9):2512-21.
Ready to submit your research? Choose BMC and benefit from:

- fast, convenient online submission

- thorough peer review by experienced researchers in your field

- rapid publication on acceptance

- support for research data, including large and complex data types

- gold Open Access which fosters wider collaboration and increased citations

- maximum visibility for your research: over 100M website views per year

At BMC, research is always in progress.

Learn more biomedcentral.com/submissions 